\title{
What reading Spinoza's Ethics out loud brings to and takes from the text
}

\begin{abstract}
"The relationship of bodies is didactic, they must learn, learn each other; such a relationship is also established (I would even say indissolubly so) through the voice." [Jacques Roubaud, The Great Fire of London]

"To speak with the words of others... that's what I'd like." [Jean Eustache, The Mother and the Whore]
\end{abstract}

o.

Spinoza Lector. In May 2017 I read Spinoza's Ethics out loud in public in a gallery space over a period of 24 hours. Or rather, I read the transcript of the previous such reading of Ethics, including all the discussion it generated, which was itself a reading of the first time Spinoza's Ethics was read out and discussed over a period of 24 hours. ${ }^{1}$ I call such events performative readings. They form part of a "book to come", The Swerve of Freedom After Spinoza (Dronsfield, 2015a). In what follows I offer a philosophical justification for the readings and outline the philosophical stakes of the project, together with the motivation for doing the readings.

\section{I.}

"One dreams of Spinoza's Ethics read by Alain Cuny." Why? Because the voice dramatises the concept. So Deleuze (2006a, 326). It seems that concepts can be acted as something like characters, "rhythmic characters" as Deleuze puts it, because their interaction with other concepts can be dramatised. One of the main concepts of Spinoza's Ethics is of course the affect. In what sense can the concept of affect be dramatised?

In a number of texts across his career, Deleuze sought to show that breaking through the surface of the Ethics, disrupting it, fracturing it, is another Ethics. This "second Ethics" affects the reader. The Ethics may be the discourse of the concept of affect, but at the same time it is a discourse which itself affects. The force of this second ethics is to be found, according to Deleuze, in one of the specific components of the Ethics, its scholia. The task is not to work out how the scholia fit into the overall conceptual development; they don't (Deleuze, 1995b; 165). If all the other component parts-definitions, explications, axioms, postulates, propositions, proofs, corollaries, lemmata, prefaces, appendices-form the discourse of the concept, then the scholia disrupt that discursive flow, dynamise it, intensify it, slow it down or speed it up, turn and de-turn it. They are the site of 
the text's affective moments. And their action is undercurrent and subterranean: Deleuze's favourite dimension because you cannot see it coming, and before you know it, it is everywhere the ungrounding of what you can see. The rhizome, the stratigraphic, the scholium. And such is the role played by the scholia that by the time we reach the final part of the Ethics, Part V, titled "Of the power of the intellect, or of human freedom", the geometric method of the previous four parts, one of exposition, has transformed into a geometric method of invention. Part V is, in short, the "third Ethics" of the Ethics.

Now, not only does Deleuze argue that there are two (or three) Ethics in the Ethics, he also, though less insistently, contends that a "double reading" of the Ethics is possible, one which he calls an "affective reading". The term "affective reading" occurs, to my knowledge, only once in Deleuze's many writings on Spinoza:

There is a double reading of Spinoza: on the one hand, a systematic reading in pursuit of the general idea and the unity of the parts, but on the other hand and at the same time, the affective reading [la lecture affective], without an idea of the whole, where one is carried along or set down, put in motion or at rest, shaken or calmed according to the velocity of this or that part. (1988: 129)

So, two Ethics in the Ethics, and two ways of reading the Ethics, where the latter pair are not reducible to or equatable with the former. There would appear to be a determinate relation between them, and it is the scholia that dramatise that relation. It would seem that if the reader of the Ethics can be affected in his or her reading of it, then the scholia play a leading role in effecting the affective charge of the text. This is what enables Deleuze to say that a non-philosopher can encounter the Ethics in such a way that they receive an "immediate" or "sudden" illumination. Of what? Pleasure for instance (Shirley's translation of the Latin Laetitia). But we must put into question the temporality implied by Deleuze here. The scholia may be the principal site of philosophy's relation to non-philosophers, they may be the Ethics' direct address to "anyone" to read it, whether philosophers or no (Deleuze, 1995a: 139-40), but this directness ought not to be equated with immediacy.

\section{II.}

Laetitia or pleasure (joy in Curley's translation), is one of the three primary or primitive affects in the Ethics, along with tristitia or pain ("sadness" in Curley's translation), and cupiditas or desire. The primary affects of pleasure and pain are introduced in E3P11. They emanate from chance encounters, encounters with bodies external to us, they form compositions with other bodies, we passively undergo such encounters, and our affections transition passively, to greater perfection if pleasure, lesser if pain. Greater perfection here means a power of activity. But we also experience active transitions, to states of greater or lesser activity. Affects, then, can be reactions or actions. In either case, the affects in question are not simply or solely bodily. The transitionings involve ideas. An affect is a relation of body to mind. But Spinoza is not a dualist. Mind and body are essentially the same. Thus, there cannot be a causal relation between them. The body does not determine what the mind thinks (E3P2). The relation is characterised in terms of adequacy and inadequacy, and relation is itself an idea inadequate 
to the "one", the "one and the same thing" that mind and body are (Spinoza, 1982: E2P7S and E3P2S). The mind is an idea of body, and what the mind thinks will adequate or not adequate to the body. If affects are produced by external causes then the mind will be passive with respect to them. We can be led astray by how affects act upon the mind. We can be ignorant of the causes of our affections. We can be unknowing of why we desire the way we do. We are vulnerable to affection. Imagination as an act of mind is inadequate and can lead us into error.

But we must hear inadequacy, vulnerability, even error, without value, or accept as a task the need to think them positively. We are felicitously vulnerable to the erotic. Imagination is an inadequate but necessary form of knowledge. It is possible to have images of things which do not correspond to the external object (E2P47S), but this can be a resource and an enrichment of the mind. Reason is adequate ideas. Reason can bring us to an understanding of our passions, those things with respect to which we are otherwise passive, such that we can have an active and adequate relation to them, where adequacy implies that we are not slaves to our passions. Equally, the passions can lead the mind to have ideas it would otherwise not have, can give it powers of activity it would otherwise not have, can reveal transitions of the body of which we would otherwise not be aware; moreover, to an awareness of how those transitions, powers and passions are themselves constitutive of thought. Indeed, the mind would have no notion of transition, and thus of change, and difference between adequation and inadequation, without the affective body.

Presentness of body, if there is such a thing, is given by affect. But affect is also what divides self-presence. Affects can as well be produced by the action of mind in reason. Transitions to reason are not separations from or the renunciation of affect. Affect is involved in all forms of thought. Thus, affect cannot be reduced to immediacy, or predicated as speed over slowness. And affective reading cannot be reduced to immediacy (as is supposed, for instance, by Dan Smith [2008: 2].)

\section{III.}

There is at least one other instance of Deleuze invoking the notion of "affective reading", when he says that the close-up in Eisenstein gives such a reading. The close-up is "both a type of image and a component of all images" (1986: 87). It is not that with the close-up one sees more closely, it is that a leap is effected; the difference is qualitative not quantitative. It is intensive. The temptation, or the presupposition, is to think this as immediacy. Intensivity is not immediacy. What is intensified is the relation of part to whole. The close-up is not partial, not a part of a greater whole, it is the affective relation to the whole, where the affect is expressed as a whole. Deleuze compares scholia to snapshots: "photographs suddenly taken, freezing the progress in temporary immobility" (1992: 349). If, as Deleuze maintains, the scholia are therefore shown not to correspond to the proposition, or what is given in the proof of the proposition, it is because the discussion is halted, and the concept under discussion seen to work less familiarly. The scholia defamiliarise what is common, and reveal the common otherwise. We should understand this not as immediacy, but as a spacing in time. 


\section{IV.}

At the end of E2P49S Spinoza says that from his account "can be drawn many excellent lessons, most useful and necessary to know" and that these will "partly be disclosed in what is to follow". If the scholia are lessons to be drawn from what has been demonstrated in the proofs, then they do not repeat what is demonstrated, they double it. They prove it again, as if for the first time. They enjoy a relative independence from what they double. Both ostensive and expressive of a first-person Spinozan "I". Could we go as far as to say more comprehensible, perhaps even more didactic? If so, they rely on examples drawn from lessons of life. The Latin scholium comes from the Greek $\sigma \chi 0$ diov, scholion, itself derived from $\sigma \chi 0 \lambda \dot{\eta}$ (school) in the sense of band, troop, company, a multitude to whom lessons might be given. But thereby do scholia run a risk. In making understood to a greater number that which is otherwise proved geometrically, that is with rigour and precision, the risk run by scholia is what Martin Heidegger (2012: 97) calls "massiveness", one of the ways in which modern humanities' abandonment of being is covered over.

The sense of $\sigma \chi 0 \lambda \dot{\eta}$ that Heidegger is alluding to is that of time, leisure time or free time, in which those with no practical imperative to do otherwise might spend in gaining wisdom-for instance in discussion or disputation, or in speculative inquiry. The question of speed is imperative here. If the Ethics can be read as a composition — of speeds, of slownesses, of differential rhythm - then the way in which the scholia rhythm the text, give time to the text and make time within it, cannot be separated from the time to learn from what it says. If, then, the scholia are lessons of life, they are abstractions from, but not separate from, its practical necessities, ways of giving time in the flow of life. Scholia are ways of giving time in the reading of the text, a time which is not reducible to the linear causal one of reason's demonstrations. Thus, in the reading of them out loud, one must give the scholia time to create a time, a time in which to think whether and to what extent Spinoza affirms practical joy, for instance, as the outcome of his theoretical method.

How, then, is the Ethics to be read out loud if an affective reading of it is to be given? If a reading out loud of the Ethics that Deleuze dreams of is to do justice to it, then the scholia might need to be read in such a way as to allow them their disruptive force; or it could be a reading which would dramatise the concept such as to show the affect upon it of the scholia, or one which accords the scholia a different tone, one of "underneathness". Or maybe the drama occurs only in the final act. Or perhaps it would be a rendering of the scholia only. Read on their own the scholia would be "Spinoza's anti-Bible" (Deleuze, 1997: 146).

\section{V.}

Paul Saenger (1997: 13) points out that ancient texts could not but be uttered out loud if they were to be understood, for their words were not separated, they were written as scriptura continua, continuous and uninterrupted. It was in the written Latin of the central Middle Ages that the orthographical practice of word separation came to be the norm, and with word separation came silent reading. For Peter Kivy (2006: 18) silent reading is not an ontological break with reading aloud, it is a "logical step" into another kind of performance of the text, but no 
less a performance for that. Kivy argues that all silent reading is performance art, that silent readings are performance art works, that silent readers are performing artists. But Kivy is eliding the necessity of word separation with reading. Texts in their being uttered out loud were not being read in the same way that we might say that we read a book out loud, they were being made into texts. To utter out loud a text written with words not separated was not to perform the text, it was to make it readable. In order to be comprehended, texts written as scriptura continua had to be made to sound out loud, to work out the rhythming and disjoining, the articulation and disambiguating of the writing. And in order to be made to sound out loud they needed to be spaced.

The necessity of spatialising text was such that the words had first to be separated from the paper in order to be separated from each other, and at the same time made audible, made public, public to oneself, in order that they could then be uttered internally and said silently. For the "eyes only" to read, the words had first to be made available to the ear. Reading-to-oneself as a silent practice may have followed on from reading out loud, but that sounding of the text is not the same as reading it. Silent reading can be much quicker than reading aloud, for Kivy because it comes closer to the speed of human thought. In her review essay of Kivy's book, Susan L. Feagin (2008: 94) points out that this is because human thought "can do its cognitive job" without knowing or worrying about how the words should or would sound or be pronounced. But anyone who has seen Billie Whitelaw or Lisa Dwan performing Samuel Beckett's Not I will know that texts can be spoken aloud more quickly than they can be read silently or even thought. Moreover, no-one could do a "cognitive job" on Not I without wondering how the words sound.

It does not necessarily follow that those who perform or vocalise the text, and act precisely those things that enhance the reading, grasp cognitively what is being said. Whilst agreeing with Feagin's objection to Kivy, that he fails to appreciate the distinction between reading silently and performing silently, we object to her privileging cognition over the material sounding and spacing of words, and we do so precisely through something she herself appeals to in her critique: "affective flexibility".

\section{VI.}

To read performatively out loud is to read with the affective flexibility produced by the combination of bodies. To read performatively out loud is to read subject to and subject of the affectivity of there being another body in combination with one's own. And that body can be one's own. To read performatively out loud is to read with another body with which to combine sensuously in the acts of reading and listening. And that audience can be oneself. In its reading out loud, the self is the sound of a voice which separates one from oneself. Conjoined with and disjoined from one's own body under the condition of affect. One's voice has the capacity to affect oneself:

For the human body is composed of very many individual bodies of different nature, and so it can be affected by one and the same body in many different ways. (E3P17S)

From this, Spinoza adduces what he calls the vacillation of emotion, correlative with the relation doubt has to imagination. But is there not a vacillation internal 
to the concept of emotion? We feel, then we doubt, whether that be because we are subject to a conflicting emotion, or because the intellect intervenes in order to make itself adequate to the feeling. To this extent we may wonder whether it is possible, temporally, ever to be affected by just a single emotion. We argue here that one's own body can be both the internal and external affective cause upon itself and be both a direct and indirect affective cause to itself. One such way is through the voice and hearing oneself speak: hearing oneself say something for reasons which are unclear to one, and that one may even disagree with; hearing oneself say something "unintentional", yet for which one must accept responsibility.

Why is it that if one is reading out loud the words of another it becomes difficult to listen to the meaning of what one reads? The experience of reading the text of another differs from that of reading one's own text. But can that difference be explained simply by the fact that one has written what one reads, or that one knows what one has written before reading it? One's own written words can sound unrecognisable when one hears them read out loud. Even one's ownmost, one's most intimate written words, if read out loud by another, can sound as if written by another. One's ownmost written words can seem foreign if one hears them read out loud even by the very addressee of them. When in the closing sequence of Michelangelo Antonioni's La Notte Lidia (Jeanne Moreau) reads aloud to Giovanni (Marcello Mastroianni) a love letter, he asks who wrote it. You did, she says. He takes his having written the letter as proof that he loves her. She takes his not remembering that he wrote it as evidence that he does not.

To try and listen to what one is saying when one reads out loud is not the same as to try and listen to what one is reading when one reads out loud. To try and listen to what one is reading is to try and understand it at the same time as speaking it. If one is reading out loud to another then one might be aware of the tone and the rhythm of the words one reads, but this would be in tension with, if not at the expense of, the meaning of those words. But how could one adjudge how to read apart from what it is one reads, is one not reading the words in order that they become better able to be understood? In reading out loud and at the same time trying to understand the meaning of what one reads, it is as if something of my own body withdraws. If I am to understand what I have read then I must follow this other in me, I must go after the other in me. I must separate myself from my own voice in order to hear it. It is as if I must participate in the collective act of listening to me.

\section{VII.}

To understand what Deleuze (2006a: 326) means by the "dramatization of the concept", we must look elsewhere than in the one-page text in which he says it and turn to his early work (2004 and 2006b). Dramatisation is a method derived from Nietzsche, specifically Nietzsche's insight that concepts are symptoms of forces without which they could not be thought. To dramatise a concept would be to draw out and make sensible the plural forces acting upon it. To dramatise a concept would be to make explicit those otherwise unseen, unheard forces in terms of their spatio-temporal dynamisms. This involves interpreting and evaluating the differential relation between the forces at work operating on the concept in the one or the text putting it to use, where the one or the text are 
to be understood not psychologically, but perspectivally, as complexes of spaces and times. If as we have discussed the concept is rhythmed by the text which presents it then the actor makes these movements audible in space and time (Deleuze, 2006a: 326).

Do we want to hear Spinoza's words acted, or would we rather hear them simply read aloud, spoken, declaimed? The risk of acting them is that they be interpreted and thus overdetermined as to their truth: each time different. The danger of declamation is that the truth of the text is presupposed and thus essentialised: each time the same. Between the identity of the one doing the representing, and the resemblance of what is being represented, what is needed is the creation of a non-representational space of thought with which to encounter Spinoza's words. And that space can be achieved by treating the text as something like a composition or an architecture, formations and ecologies of space organising the movement of flows and intensities.

If the reading out loud of a text is to be the production of a space of thought, if one is to set up at least the possibility of understanding what one reads aloud, and of being affected by it, then one must overcome a servility to the text, and rather than wait for the text to speak, or expect it to, become its master in order to make it speak. No, not to "make" a text speak, but to let it speak. Letting be is not a passivity in the face of what one reads, it is not a servile imitation or simple repetition of the text, it is to allow to appear what one reads, by giving what one reads an appearance, a face, by giving voice to it. When I speak of a performative reading, I do not intend by that term to imply that the text is acted, still less interpreted. I mean that the problem of which the text treats is performed, and in the case of the text in question, Spinoza's Ethics, this requires that the lines are read out under the condition of affect, in the same way that when one speaks to another one does so through one's face.

We have set out how for Spinoza thought can never be separated from body, and how body is never without affect. Consonant with Deleuze, a new concept of affect would be nothing if it did not afford us not just a new understanding of affect, but a new perception of it. A new understanding of affect is not possible separate from a new perception of it. And if we are talking about affect, then a new perception of affect would bring with it an entire conceptual-perceptual affective space within which it is perceived. At the same time, it is not enough to assert this, but to demonstrate it in terms of its effects. Or rather, to hold the words open for such demonstration, to incarnate them, to ex-posit them. Hence the decision in Spinoza Lector to read out loud not just Spinoza's Ethics, but the entire discussion generated by each previous reading. This in the hope of setting up a space of thought in which the drama of thinking could be seen to be taking place.

It is a question of responsibility. Simply to read the text reliant on what it has to state about affect as a concept would be an irresponsible reading, it would be to presume in advance that the concept needs only its abstract theoretical presentation, and not an actual affective exposition in order to be understood. Hence the call for participants in the reading to "de-abstract and actualise" Spinoza's concepts under what Lyotard (1991, xvii) calls "the responsibility of mouths and eyes of the flesh". The question of whether actualising a concept means dramatising it in the manner of a drama is one that can only be answered in the vocalising of it: in the vocalisation both of the question and of the concept the question is 
addressed to. And the answer will be multiple and equivocal in the sense that there will be more than one voice incarnated. A concept is both differential in itself, subject to and of multiple forces; and differentiated in its actualisation, set in relation to other concepts. A creative reading would need to perform both; a performative reading would need to create both.

Thus, part of the motivation for Spinoza Lector is to unfold the question whether an affective reading can be achieved performatively. Performative reading is the performance of a problem rather than discussion of or about that problem. One can discourse on the question of what an affective reading is; or one can put into question what it is to read affectively by performing the problem. The question of what an affective reading is, is best approached, we argue, through discussing it under the condition of being affected in the reading. To the objection that what is being talked about here is an affected reading, we say that all reading is affected, that there has never been a reading which is not under the condition of one affect or another.

The necessity of an affective reading out loud of Spinoza's Ethics of the sort that I have set out might be said to draw support from something Spinoza himself says: "Nothing exists from whose nature an effect does not follow" (E1P36). It is not enough simply to state or assert what follows. One must demonstrate what follows not just theoretically in terms of a proof, but practically in terms of its effects. Warren Montag (1999: 3) is right to say that these two activities "depending upon circumstances, do not necessarily coincide". It is in the non-coincidence that a risk emerges. With respect to the question of an affective reading, the risk is that in reading Spinoza in such a way as to draw out the affectivity of the scholia (or any other part of the text), the reason which may produce ideas adequate to what an affective reading is will not be given the time or space to do its work. The economy of the affections could become such as to denude reason of its chance to reveal ideas with which to make sense of the affects we seek to accentuate. But this risk is at once a chance and becomes a necessary risk if we wish to know what effects follow from the affections of the body. We would not know of what the mind is capable unless we were to test the limits of the body.

\section{VIII.}

There is another reason why if one is to encounter a text under both aspects of a double reading it is not sufficient simply to read a text out loud word-for-word. For there are words which are given by any text to be read out differently than how they are written, according to the way they are subject to the manners of the time in which they are uttered. Such words are to be found in the margin. Spinoza discusses this when treating of words which, innocent in the mouths of "writers of old", came to have an obscene sense "when vice and intemperance were rife":

There was no need to alter Scripture on this account, but in concession to the weak-mindedness of the common people they introduced the custom in public readings of substituting more acceptable words for sexual intercourse and excrement, as are marked in the marginal notes. (TTP ch. 9, $\$ 18=2002,487$ )

On the one hand we might take this to be an unnecessary and unwanted paternalism (we need no persuading of Spinoza's ambivalence towards "the common 
people"), which raises the unanswerable question "who decides?" But we could also take it as an understanding on Spinoza's part of the materiality of the letter of the word, and that such materiality is as much a matter of its reading as it is of its writing. And again, we may say that the marginalisation of certain words deemed unacceptable by the manners of the time, in favour of what is written in the margin, is another form of spacing, and a space of thought.

\section{IX.}

According to Deleuze, Spinoza is a paradox because in his method he is "the most philosophical of philosophers", yet in how he goes beyond method "the one who more than any other addresses nonphilosophers". And what is meant here by "non-philosophical understanding" is affect. The reader is affected by the intensity of the Ethics' non-philosophical address:

absolutely anyone can read Spinoza, and be very moved, or see things quite differently afterward, even if they can hardly understand Spinoza's concepts. (Deleuze, 1995b: 165-166)

An affective reading of Spinoza could begin anywhere within the Ethics without an idea of the whole. In order to test this proposition the decision was made to read Spinoza's Ethics over a period of 24 hours, in a public gallery space which anyone could enter or re-enter at any time. The resultant transcripts (published as books, Dronsfield, 2017a and 2017b) attest to the fact that chance encounters and wanderings in and participation of passers-by and non-philosophers in both the reading and discussion all took place.

Another motivation for doing the performative reading was to ascertain whether the two folds of a "double reading", discursive and affective, could be enfolded by one and the same reading, whether one could intensify the other. How else to unfold seriously the question that unless the reader appreciates both ways of reading Spinoza, then they have not read him. On the one hand, the whole is not possible without an affective reading, without in this case the turnings and de-turnings of the discursive and the temporal spacing within it that the scholia are. On the other, someone without an idea of the whole can be affected by the close-up of the scholia such that they gain an impression of the whole. Reading performatively not just Spinoza's Ethics out loud, but the discussion generated by the previous reading too, in turn produces more discussion, in other words further disputation, doubt, disorder, chaos, clarity-all good conditions for the emergence of the intellect. It is a space of thought both discursive and affective. But it is important to stress that its being durational over a period of 24 hours makes it extremely difficult to tell where, if at all, the dividing line falls between the discourse and affect, between mind and body. There is a gap, but that gap is not fixed, nor decided in advance of the event of reading. This is another aspect of performativity - to effect a gap, to hold open that gap, and to tense the self by it. It is this gap that is productively exploited by Moira Gatens (2014) and Pierre Macherey (1996) with what they have to say about joy in Spinoza (and Deleuze), in particular "joyful deliberation" and "joyful passions" respectively. 


\section{$\mathbf{X}$.}

We might say that an affective reading (of, say, a book, for example Spinoza's Ethics) is one which opens up a way to assist the subject in attaining subjectivity, an exposure which would open a way for the subject to understand the passions to which she finds herself subject, a way which would enable her to achieve what we might say is the double-genitivity of subjectivity, whereby the subject becomes both subject to and subject of her passions. We find an example of just such an affective reading of Spinoza in Judith Butler, in how she is first exposed to philosophy, as a young teenager taking refuge from the terror of family in the basement of the home and by chance encountering Spinoza's Ethics:

My emotions were surely rioting, and I turned to Spinoza to find out whether knowing what they were and what purpose they served would help me learn how to live them in some more manageable way. (2004: 235)

We do not know, she does not say, whether Butler reads Spinoza to herself silently, or out loud.

\section{XI.}

As is well known, Ethics was not published in Spinoza's lifetime, and when it did appear it did so anonymously. Indeed, having distributed the manuscript to a small number of friends, his readers, Spinoza stopped a translation of it into Dutch from being made, in the belief that it was only the fact that it existed in Latin that prevented it from being banned. Then can we say that the scholia are Spinoza's way of appending his signature to the text? After all, we find there a use of the first-person pronoun which appeals to experience, lessons of life, and to the doing of living. If Spinoza is concerned with what follows on one from the other in the order of things, then we might take the scholia as subtle syncopation of lines of thought. And we might say of Spinoza that with the scholia he sought to let quietly resonate the human voice in philosophy. A reintroduction of the human voice into philosophy and philosophy to the human voice: silently contra Descartes. For Spinoza not to sign his work is an autobiographical repression of his signature. As the site of the subjectification of the concept, where the affective is drawn out in its disruptive and productive effects upon the concept, we might say that the scholia are where, in a text which nowhere mentions the voice, and which discusses sound only in the scholia or appendices, Spinoza's voice may be heard, a voice without a name, a writing which sounds the voice in order to make room for a name which could not be written. Would it be going too far to suggest that the scholia are the affective dramatisation of the conatus of the proper name "Spinoza"? 
Italy: Nepi Film et al.

Beckett, S. (1973). Not / [1972] London: Faber and Faber.

Butler, J. (2004). Undoing gender. London: Routledge.

Deleuze, G. (1981). Spinoza, Philosophie pratique [1970]. Paris: Les Éditions de Minuit.

(1983). Cinéma 1, L'imagemouvement. Paris: Les Éditions de Minuit.

(1986). Cinema 1, The movement-image. $(\mathrm{H}$. Tomlinson \& B. Habberjam, Trans.). London: The Athlone Press.

(1988). Spinoza, practical philosophy [1970]. (R. Hurley, Trans.). San Francisco: City Lights Books.

(1992). Expressionism in philosophy: Spinoza [1968]. (M. Joughin, Trans.). New York: Zone Books.

(1995a). On philosophy [1988]. In Negotiations 1972-1990 (pp. 135-155). (M. Joughin, Trans.). New York: Columbia University Press.

(1995b). Letter to Reda Bensmaïa, on Spinoza [1989]. In Negotiations 1972-1990 (pp. 164-166). (M. Joughin, Trans.). New York: Columbia University Press.

(1997). Spinoza and the three "Ethics" [1993]. In Essays clinical and critical (pp. 138-151).
(D. W. Smith \& M. A. Greco, Trans.). Minneapolis: University of Minnesota Press.

(2004). The method of dramatization [1967]. In Desert Islands and other texts 1953-1974 (pp. 94-116). (M. Taormina, Trans.). New York: Semiotext(e).

(2006a). What voice brings to the text [1987]. In Two regimes of madness, texts and interviews 1975-1995 (pp. 325-326). (A. Hodges \& M. Taormina, Trans.), New York: Semiotext(e).

(2006b). Nietzsche and Philosophy [1962]. (H. Tomlinson, Trans.). London: Continuum Books.

Dronsfield, J. L. (2013), Where narrative stops. Interview with Wilkinson Gallery, London. SARMA: Laboratory for Discursive Practices and Expanded Publication, http:// sarma.be/docs/3053.

Bloomington: Indiana University Press.

Kivy, P. (2006). The Performance of reading: An essay in the philosophy of literature. Oxford: Blackwell.

Lyotard, J-F. (1991). Foreword: After the words. In Joseph Kosuth, art after philosophy and after: collected writings 1966-1990 (pp. xv-xviii). Cambridge, MA: MIT Press.

Macherey, P. (1996). The encounter with Spinoza. (M. Joughin, Trans.). In P. Patton (Ed.), Deleuze: A Critical Reader (pp. 139-161). Oxford: Blackwell.

Montag, W. (1999). Bodies, Masses, Power: Spinoza and His Contemporaries. London: Verso.

Roubaud, J. (1991). The Great Fire of London: A story with interpolations and bifurcations [1989]. (D. Di Bernardi, Trans.). Elmwood Park, IL: Dalkey Archive Press.

(2015a). CONTENTS [2011]. In Pli, The Warwick Journal of Philosophy, 27, special issue on Spinoza: The Proper Order of Philosophy, 79-80.

(2015b). The artistphilosopher and the pathology of enthusiasm. Interview with Stefan lancu for Samizdat and Revista Arta. SARMA: Laboratory for Discursive Practices and Expanded Publication, http:// sarma.be/docs/3052.

(2017a). Spinoza Lector (Berlin). London: Office of the Dismissed.

(2017b). Spinoza Lector (Brusse/s). London: Office of the Dismissed.

Eustache, J. (1973). La maman et la putain [The mother and the whore]. France: Elite Films et al.

Feagin, S. L. (2008). Critical study: reading and performing. British Journal of Aesthetics, 48(1), 89-97.

Gatens, M. (2014). Affective transitions and Spinoza's art of joyful deliberation. In M-L. Angerer, B. Bösel and M. Ott (Eds.), Timing of Affect: Epistemologies, Aesthetics, Politics (pp. 17-33). Zürich: Diaphanes.

Heidegger, M. (2012).

Contributions to philosophy (of the event) [1936-8]. (R. Rojcewicz \&D. Vallega-Neu, Trans.).
Saenger, P. (1997). Space between words: The origins of silent reading. Stanford: Stanford University Press.

Smith, D. W. (2008). On philosophical virtuosity; or: how to read Deleuze. In Proceedings of Annual Meeting of the Society for Phenomenology and Existential Philosophy. Pittsburgh, Pennsylvania.

Spinoza, B. (1982). The ethics (S. Shirley, Trans.). Indianapolis: Hackett Books.

(1985). The collected works of Spinoza, volume 1. (E. Curley, Trans.). Princeton: Princeton University Press.

(2002). Theological-political treatise [1670]. In Complete works (pp. 383-583). (S. Shirley, Trans.). Indianapolis: Hackett Books. and selected letters [1660-77].

\section{ENDNOTES}

1 Spinoza Lector has been performed in: No-One Knows What a Body Can Do? curated by Kathrin and Sarah Oberrauch, Lanserhaus, Eppan, Italy, 27.05.2017-25.06.2017; Pharmakon: Whitch Culture? A Performative Conference, Kaai Theater Studios, Brussels, Belgium, 28.11.2014-30.11.2014; Raum N Gallery, Berlin, in Justifiable Version of Events: Catastrophe, curated by the Jan Van Eyck Academie Alumni Association, 21.07.2014 26.07.2014. For more on Spinoza Lector see Dronsfield 2013 and 2015b. 